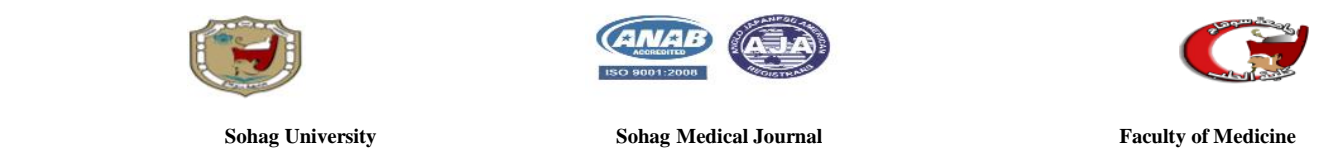

\title{
Predictive Factors of Complications of PNL in Solitary Kidney: A Prospective Study
}

\author{
Ahmed Sabri Mahmoud, Mohamad Dyaa Sayed Saleem, Mohammed Saber \\ Khalaf, Elnisr Rashed Mohamed
}

Department of Urology, Sohag University Hospital, Sohag, Egypt

\begin{abstract}
Objectives: To analyze factors that can impact the intraoperative and postoperative complications and hemorrhage after percutaneous nephrolithotomy (PNL) in patients with a solitary kidney.

Material and Methods: A prospective hospital-based study that was carried out at the Urology Department, Sohag University Hospital from June 2017 to June 2019. All patients with renal calculi in a solitary kidney were recruited and underwent PNL.

Results: 150 patients were enrolled in this study. 93 (62\%) patients were males while 57 (38\%) patients were females. Initial SFR was achieved in 129 (86\%) patients while residual fragments were reported in 21 (14\%) patients. $39(26 \%)$ patients had postoperative complications. On univariate analysis, the rate of complications was associated with the complexity of the stones, acute dilatation of the tract, and operative time $(\mathrm{P}$-value $=0.048,0.004 \& 0.023$ respectively $)$. On the other hand; there was an association between the number of the accessed tracts and the rate of bleeding and blood transfusion $(\mathrm{P}$-value $=0.008)$.

Conclusion: PNL is a challenging procedure in solitary kidneys; however high SFRs can be done with a low rate of major complications. The complexity of the stones, acute dilatation of the tract, and prolonged operative time are associated with more complications. Multiple tracts have a significant effect on intraoperative bleeding. PNL is an effective choice for patients with stones in a solitary kidney.

Keywords: Complications, Solitary kidney, PNL
\end{abstract}

\section{Introduction:}

The recommendations of The European Association of Urology identify patients with a single kidney as a high risk for stone formation. The risk of stone formation is not increased by the kidney itself but recurrence prevention is an important issue (1)(2). Stone in an only functioning kidney is an endourologist's management dilemma. The privilege of bilateral kidneys is not present and an injury to the only functioning kidney will lead to major morbidity (3). PNL was firstly introduced in 1976 as a method of treatment for kidney stones (4).

In literature, PNL in patients with solitary kidney might have a higher risk of complications than in patients with bilateral kidneys. Although PNL is related to serious outcomes, e.g. hemorrhage and pleural injury, it remains the best option for multiple renal stones even if the patient has a single kidney (5). However; the operator should balance 
the need for therapeutic success with the patient risks (6).

This study aims to analyze factors that can impact the intraoperative and postoperative complications and bleeding and evaluate the renal function changes after percutaneous nephrolithotomy (PNL) in patients with a solitary kidney. While there has been only one prospective study about that topic ${ }_{(7)}$, critical appraisal remains under-reported.

\section{Material and Methods:}

Study Design: A prospective hospitalbased study that was carried out at the Urology Department, Sohag University Hospital from June 2017 to June 2019 after approval by the Institutional Review Board of Faculty of Medicine, Sohag University. Patients with renal or upper ureteral stones equal or more than $1 \mathrm{~cm}$ in an only functioning kidney were included. Cases with serum creatinine > $2 \mathrm{mg} / \mathrm{dl}$, under 18 years old or had abnormal bleeding profiles were excluded from the study.

Preoperative Patient's evaluation: All patients were evaluated by a full history taking, complete examination, serum creatinine, eGFR, routine laboratory investigations and imaging by abdominal ultrasound, KUB film, non-contrast Computed Tomography (NCCT) and/or Intravenous Urography (IVU). The hydronephrosis was classified by the grading system of the Society of Fetal Urology (SFU) into mild hydronephrosis (SFU III), moderate hydronephrosis (SFU III) and severe hydronephrosis (SFU IV) (8). The complexity of the stone was determined according to Guy's stone score (GSS) (9). eGFR was measured by the Chronic Kidney Disease Epidemiology Collaboration (CKD-EPI) formula (10). The stone burden was estimated using the following formula: surface area (SA)
$=$ length $\times$ width $\times \Pi \times 0.25(\Pi=3.14159)$ (11).

Operative Technique: Preoperative preparations included intravenous 3rd generation cephalosporin 2 hours before surgery. Briefly, all PNL were performed under general anesthesia and in a prone posture. The insertion of a 6 Fr ureteric catheter was done by the cystoscope in a lithotomy position. Opacification of the renal collecting system was done by iodinated contrast in a retrograde manner under fluoroscopy in a prone posture, and then puncture sites were selected according to stone distribution. The tract was dilated by Teflon dilators (gradual or acute) up to 24-26 French. Acute dilatation is defined as one-shot dilatation (12). Nephroscope 26 Fr with outer sheath, 24 Fr without the outer sheath, and pneumatic disintegrator were used. A twenty French nephrostomy tube was inserted and clamped for 2 hours. The ureteral catheter was fixed to a Foleys catheter. However, it was replaced by double $\mathbf{J}$ stent in 75 patients who had multiple stones, staging stones, intraoperative perforation, or extravasation. Operative time was measured from the first renal puncture until all stones were completely removed.

Postoperative care: Close monitoring of the vital signs and urine output. Complete blood count (CBC), serum creatinine and eGFR were done in the next morning after the operation. Abdominal U/S, plain film, and NCCT were done the next day. Ureteral catheter and nephrostomy tube were removed after 24 hours provided that there was neither postoperative bleeding nor significant residual fragments after NCCT. If there was no fever, pain, or leakage the patient was discharged. The double $\mathbf{J}$ stent was removed after 4 weeks if 
NCCT revealed no residual stones and abdominal U/S revealed no hematoma. Success is defined as no significant residual stones (fragment $4 \mathrm{~mm}$ or less, non-obstructive, non-symptomatic, and non-infectious). Complications were reported and categorized by the modified Clavien classification system.

Follow up: it was done by serum creatinine and eGFR every one month for three months.

\section{Statistical analysis:}

Data were analyzed by IBM SPSS Statistics for Windows version 26.0. Quantitative data were expressed as a median. Qualitative data were expressed as number and percentage. Quantitative data were tested for normality by the
Shapiro-Wilk test. Binary logistic regression analysis was used to determine predictor variables of complications and bleeding among the studied patients. A 5\% level was the level of significance in all statistical tests used in the study. The significance level was set up at $p<0.05$.

\section{Results:}

1- Preoperative patient and kidney characteristics:

The current study included 150 patients with calculi in a solitary kidney. 93 (62\%) patients were males while $57(38 \%)$ patients were females. The median age was 45 years. The median BMI was 27 $\mathrm{Kg} / \mathrm{m}^{2}$ (Table 1).

\begin{tabular}{|c|c|}
\hline Variables & Summary statistics \\
\hline $\begin{array}{c}\text { Gender: } \\
\text { Female } \\
\text { Male }\end{array}$ & $\begin{array}{l}93(62 \%) \\
57(38 \%)\end{array}$ \\
\hline Age (year) & $45(30-55)$ \\
\hline BMI & $27(25.75-29)$ \\
\hline $\begin{array}{l}\text { Etiology of solitary kidney (Contralateral } \\
\text { kidney): } \\
\text { Atrophic (small sized) } \\
\text { Congenital agenesis } \\
\text { Functional solitary kidney (echogenic or } \\
\text { chronic pyelonephritic) } \\
\text { Nephrectomised }\end{array}$ & $\begin{array}{c}27(18 \%) \\
6(4 \%) \\
96(64 \%) \\
21(14 \%)\end{array}$ \\
\hline $\begin{array}{l}\text { Degree of hydronephrosis: } \\
\text { Mild hydronephrosis } \\
\text { Moderate hydronephrosis } \\
\text { No hydronephrosis ( } 24 \text { patients with previous } \\
\text { nephrostomy tube) }\end{array}$ & $\begin{array}{l}45(30 \%) \\
27(18 \%) \\
78(52 \%)\end{array}$ \\
\hline Creatinine (mg/dl) & $1.1(0.9-1.36)$ \\
\hline eGFR $\left(\mathrm{mL} / \mathrm{min}\right.$ per $\left.1.73 \mathrm{~m}^{2}\right)$ & $72.05(55.43-84.9)$ \\
\hline
\end{tabular}

Table 1:

Preoperative patient and kidney characteristics.
Regarding the stone criteria; 72 (48\%) patients had multiple stones. Stones were radio-opaque in $114(76 \%)$ patients while they were radiolucent in $36(24 \%)$ patients. The median stone burden was $314 \mathrm{~mm}^{2}$. The median stone density was 1039 HFU (Table 2). 
SOHAG MEDICAL JOURNAL Vol. 24 No. 2 April 2020
Predictive Factors of Complications of PNL in Solitary Ahmed Sabri Mahmoud

\begin{tabular}{|c|c|}
\hline Stone characteristics & Summary statistics \\
\hline Site of stones: & \\
\hline Lower calyx & $27(18 \%)$ \\
\hline Middle calyx & $3(2 \%)$ \\
\hline Upper calyx & $6(4 \%)$ \\
\hline Upper third ureter & $3(2 \%)$ \\
\hline Pelvic & $39(26 \%)$ \\
\hline Multiple & $72(48 \%)$ \\
\hline HFU (stone density) & $1039(636-1441)$ \\
\hline Opacity: & \\
\hline Lucent & $36(24 \%)$ \\
\hline Opaque & $114(76 \%)$ \\
\hline Stone Burden $\left(\mathrm{mm}^{2}\right)$ & $314(152-506)$ \\
\hline Stone side: & \\
\hline Left & $84(56 \%)$ \\
\hline Right & $66(44 \%)$ \\
\hline Guy's Stone Score (stone site): & \\
\hline GSS1 & $51(34 \%)$ \\
\hline GSS2 & $57(38 \%)$ \\
\hline GSS3 & $42(28 \%)$ \\
\hline
\end{tabular}

Table 2: Stone characteristics.

\begin{tabular}{|c|c|}
\hline Intra operative data & $\begin{array}{c}\text { Summary } \\
\text { statistics }\end{array}$ \\
\hline $\begin{array}{l}\text { Stone free rate: } \\
\text { Initial } \\
\text { Final }\end{array}$ & $\begin{array}{l}129(86 \%) \\
141(94 \%)\end{array}$ \\
\hline $\begin{array}{l}\text { Auxiliary } \\
\text { procedures: } \\
\text { 2nd look PNL } \\
\text { DJ insertion } \\
\text { No }\end{array}$ & $\begin{array}{c}12(8 \%) \\
4(2.7 \%) \\
134(89.3 \%)\end{array}$ \\
\hline $\begin{array}{l}\text { Numbers of tracts } \\
\text { One } \\
\text { Two }\end{array}$ & $\begin{array}{c}134(89 \%) \\
16(11 \%)\end{array}$ \\
\hline $\begin{array}{l}\text { Site of tracts } \\
\text { Lower calyx } \\
\text { Middle calyx } \\
\text { Middle and } \\
\text { lower } \\
\text { Upper calyx }\end{array}$ & $\begin{array}{c}125(83.3 \%) \\
3(2 \%) \\
16(10.7 \%) \\
6(4 \%)\end{array}$ \\
\hline $\begin{array}{l}\text { Dilatation } \\
\text { Acute } \\
\text { Gradual }\end{array}$ & $\begin{array}{l}117(78 \%) \\
33(22 \%)\end{array}$ \\
\hline $\begin{array}{l}\text { Operative time } \\
\text { (min) }\end{array}$ & $25(20-60)$ \\
\hline Hospital stay (days) & $2(1-3)$ \\
\hline
\end{tabular}

Table 3: PNL outcomes and operative data.
GSS: Guy's stone score

\section{2- Patients outcomes:}

All PNL were done in a prone position and the majority of patients had a single puncture performed (92\%). Initial SFR was achieved in $129(86 \%)$ patients while residual fragments were reported in $21(14 \%)$ patients. Second look PNL was done for 12 patients $(8 \%)$; thus, the final SFR was achieved in 141 (94\%) patients. Follow up was decided for the last nine patients $(6 \%)$ as they had non obstructing small residual stone fragments. The median operative time was 25 minutes. The median hospital stay was 2 days (Table 3 ).

There was a slight rise in the postoperative serum creatinine by 0.08 $\mathrm{mg} / \mathrm{dl}$ and a decrease in the postoperative eGFR by $5.75 \mathrm{~mL} / \mathrm{min}$ per $1.73 \mathrm{~m}^{2}$ (P-value <0.001) However; Postoperative follow up demonstrated significant improvement in serum creatinine and eGFR after 3 months (Pvalue $<0.001)$.

$39(26 \%)$ cases had complications after the procedure; 28 cases were modified Clavien 2 (8 patients had pyrexia treated with antimicrobial agents, 9 patients had urinary leakage from nephrostomy site that resolved spontaneously and 11 patients with intraoperative bleeding required blood transfusion). Modified Clavien 3a complications were reported in 9 patients; double $\mathbf{J}$ stent was inserted for 3 patients with persistent leakage; double $\mathrm{J}$ insertion for azotemia due to obstructed kidney by blood clots in one patient, while chest tube was inserted for 5 patients due to hydropneumothorax. Serious complications were reported in two patients; one patient needed chest 
SOHAG MEDICAL JOURNAL

Vol. 24 No. 2 April 2020
Predictive Factors of Complications of PNL in Solitary Ahmed Sabri Mahmoud tube insertion and ICU admission, whereas the last patient had a cardiac arrest and died as he had a preoperative cardiac disease (Table 4).

\begin{tabular}{|c|c|c|c|}
\hline Grades & complications & $\begin{array}{l}\text { Number of } \\
\text { patients }\end{array}$ & \multirow{9}{*}{$\begin{array}{l}\text { Table 4: } \\
\text { Perioperati } \\
\text { ve } \\
\text { complicatio } \\
\text { ns } \\
\text { according } \\
\text { to modified } \\
\text { Clavien } \\
\text { classificatio } \\
\text { n system. }\end{array}$} \\
\hline Grade I & - & - & \\
\hline Grade II & $\begin{array}{l}\text { Bleeding requiring blood transfusion } \\
\text { Pyrexia treated with non prophylactic antimicrobial } \\
\text { agents } \\
\text { Urinary leakage - watchful waiting }\end{array}$ & $\begin{array}{l}8 \\
9\end{array}$ & \\
\hline $\begin{array}{l}\text { Grade } \\
\text { IIIa }\end{array}$ & $\begin{array}{l}\text { Persistent urinary leakage need DJ stent } \\
\text { Hematuria requiring blood transfusion + } \\
\text { Obstructed kidney + Azotemia need DJ stent } \\
\text { Hydropneumothorax need chest tube insertion }\end{array}$ & $\begin{array}{l}1 \\
5\end{array}$ & \\
\hline $\begin{array}{l}\text { Grade } \\
\text { IIIb }\end{array}$ & - & - & \\
\hline Grade IVa & $\begin{array}{l}\text { Hydropneumothorax need chest tube insertion + } \\
\text { ICU admission }\end{array}$ & 1 & \\
\hline $\begin{array}{l}\text { Grade } \\
\text { IVb }\end{array}$ & - & - & \\
\hline Grade V & Cardiac arrest + ICU admission and Death & 1 & \\
\hline & al number of patients with complications & 39 patients & \\
\hline
\end{tabular}

On univariate binary logistic regression analysis of predictor variables of complications and bleeding, the complications rate was related to the complexity of the stones (P-value $=0.048)$. Also, acute dilatation of the tract was related to more complications $(\mathrm{P}-\mathrm{value}=$ 0.004). As well as operative time affected the rate of complications ( $\mathrm{P}$-value $=0.023$ ) (Table 5).

\begin{tabular}{|c|c|c|c|}
\hline Variables & $\begin{array}{l}\text { Complicated } \\
\quad(\text { no }=39)\end{array}$ & $\begin{array}{l}\text { Non complicated } \\
\quad(\text { no }=111)\end{array}$ & $P$ - value \\
\hline Age (years) & 48 & 45 & 0.745 \\
\hline $\begin{array}{l}\text { Guys Scoring System (stone site) } \\
\text { GSS } 1 \\
\text { GSS } 2 \\
\text { GSS } 3\end{array}$ & $\begin{array}{c}9(23 \%) \\
15(38.5 \%) \\
15(38.5 \%)\end{array}$ & $\begin{array}{l}42(37.83 \%) \\
42(37.83 \%) \\
27(24.23 \%)\end{array}$ & 0.048 \\
\hline $\begin{array}{l}\text { Numbers of tracts } \\
\text { One } \\
\text { Two }\end{array}$ & $\begin{array}{l}35(89.7 \%) \\
4(10.3 \%)\end{array}$ & $\begin{array}{l}99(89.19 \%) \\
12(10.81 \%)\end{array}$ & 0.923 \\
\hline $\begin{array}{l}\text { Renal intervention history } \\
\text { No } \\
\text { Yes }\end{array}$ & $\begin{array}{l}27(69.2 \%) \\
12(30.8 \%)\end{array}$ & $\begin{array}{l}90(81.79 \%) \\
21(18.21 \%)\end{array}$ & 0.947 \\
\hline $\begin{array}{l}\text { Previous PCN insertion } \\
\text { No } \\
\text { Yes }\end{array}$ & $\begin{array}{c}35(89.7 \%) \\
4(10.3 \%)\end{array}$ & $\begin{array}{l}91(81.98 \%) \\
20(18.12 \%)\end{array}$ & 0.917 \\
\hline $\begin{array}{l}\text { Dilatation } \\
\text { Acute } \\
\text { Gradual }\end{array}$ & $\begin{array}{c}33(84.6 \%) \\
6(15.4 \%)\end{array}$ & $\begin{array}{l}84(75.68 \%) \\
27(24.23 \%)\end{array}$ & 0.004 \\
\hline HFU (stone density) & 1200 & 935 & 0.915 \\
\hline Stone Burden $\left(\mathrm{mm}^{2}\right)$ & 276 & 314 & 0.143 \\
\hline Operative time (min) & 30 & 25 & 0.023 \\
\hline
\end{tabular}

Table 5:

Univariate binary logistic regression analysis of predictor variables of complications. 
Besides; there was an association between the number of accessed tracts and the rate of bleeding and blood transfusion $(\mathrm{P}-\mathrm{value}=0.008)($ Table 6$)$.

\begin{tabular}{|c|c|c|}
\hline Variables & & $P$ - value \\
\hline $\begin{array}{l}\text { Guys Scoring System (stone } \\
\text { site) } \\
\text { GSS } 1 \\
\text { GSS } 2 \\
\text { GSS } 3 \\
\end{array}$ & $\begin{array}{l}3(25 \%) \\
3(25 \%) \\
6(50 \%)\end{array}$ & 0.154 \\
\hline $\begin{array}{l}\text { Numbers of tracts } \\
\text { One } \\
\text { Two }\end{array}$ & $\begin{array}{l}8(67 \%) \\
4(33 \%)\end{array}$ & 0.008 \\
\hline $\begin{array}{l}\text { Renal intervention history } \\
\text { No } \\
\text { Yes }\end{array}$ & $\begin{array}{l}9(75 \%) \\
3(25 \%)\end{array}$ & 0.391 \\
\hline $\begin{array}{l}\text { Previous PCN insertion } \\
\text { No } \\
\text { Yes }\end{array}$ & $\begin{array}{c}12(100 \%) \\
0(0 \%)\end{array}$ & 0.647 \\
\hline $\begin{array}{l}\text { Dilatation } \\
\text { Acute } \\
\text { Gradual }\end{array}$ & $\begin{array}{l}9(75 \%) \\
3(25 \%)\end{array}$ & 0.462 \\
\hline HFU (stone density) & 1115 & 0.075 \\
\hline Stone Burden $\left(\mathrm{mm}^{2}\right)$ & 685 & 0.933 \\
\hline
\end{tabular}

Table 6: Univariate binary logistic regression analysis of predictor variables of bleeding.

The drop of hematocrit was positively correlated with the number of tracts.

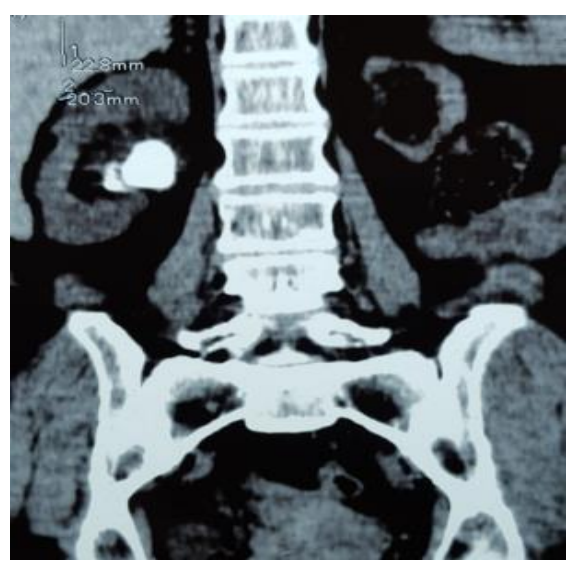

Figure 1a: Female patient 56 year old with two radio-lucent stones pelvis and lower calyx only functioning right kidney. The left kidney is small sized and atrophic.

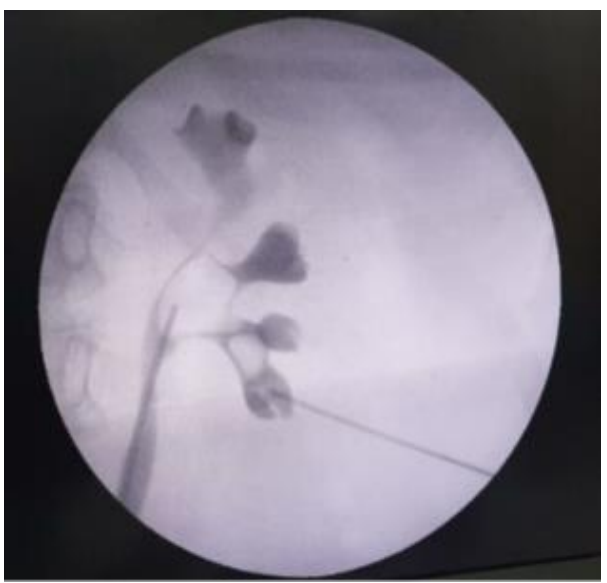

Figure 1b: Lower calyceal puncture after retrograde pyelogram under fluoroscopy 
SOHAG MEDICAL JOURNAL

Vol. 24 No. 2 April 2020

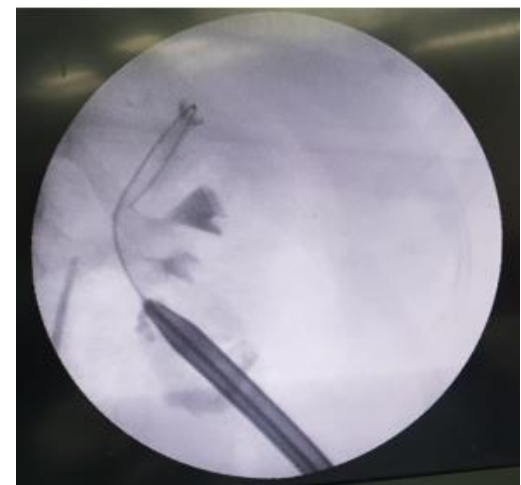

Figure 1c: Dilatation of the tract by

Teflon dilators under fluoroscopy.

\section{Discussion:}

Continuous advances in PNL instruments and techniques have helped urologists to perform it in challenging cases with high levels of protection and efficacy (13). The incidence of complications was associated with increased GSS, acute dilatation of the tract, and prolonged operative time. Also; there was an association between the number of accessed tracts and the rate of bleeding and blood transfusion. The drop-in hematocrit was positively correlated with the number of tracts.

The average complication rate in our study was $26 \%$ which was comparable to that reported in the literature. The CROES study (Clinical Research Office of Endourological Society study which is the largest study in the literature) reported a complication rate of $28.6 \%$ (5). In another study, the complication rate was $29.6 \%$ (14). Postoperative fever was reported in 8 patients $(5.33 \%)$ in the current study. Post-PNL infection is common, but only a few cases progress to SIRS or septic shock. The frequency of post PNL pyrexia ranged from 0$32.1 \%$ (15). Bootsma et al considered one major cause for postoperative pyrexia to be the operative time (16). In addition to the time of operation, complications associated with infection are correlated

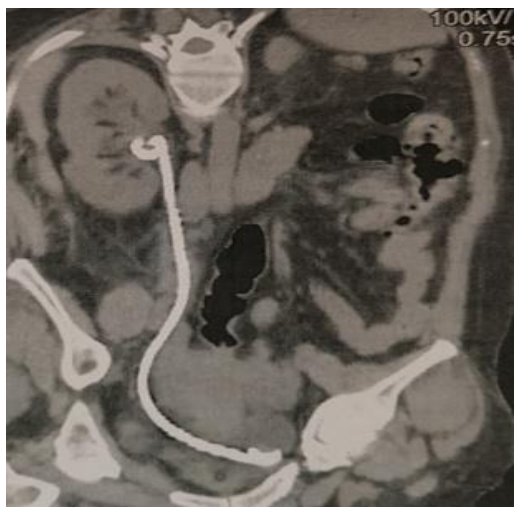

Figure 1d: Postoperative NCCT showing no residual stones and double $\mathbf{J}$ stent.

with heavy stone load, positive culture of urine, and obstructed kidney (17). In general, the leakage of urine is more obvious if wide-bore nephrostomy catheters are used, long time of catheterrization, and without ureteral drainage (18). 12 patients $(8 \%)$ had urinary leakage from the nephrostomy site which resolved spontaneously in 9 patients while 3 patients required double $\mathbf{J}$ insertion due to persistent leakage. The rate of injury to the pleura during PNL ranges from $0.3 \%$ to $1 \%$ (19) (20) (21). Supracostal percutaneous renal access is associated with a higher risk of thoracic complications $(5.3 \%)$ as compared to subcostal access $(1.4 \%)_{(22)}$. A chest tube was inserted in 6 patients (4\%) in this study due to hydropneumothorax caused by pleural injury during PNL.

In literature; the overall complication rates of PNL showed no differences between patients with single kidney and bilateral functioning kidneys. However, puncturerelated complications in a single functioning kidney are more likely to have uncontrolled hemorrhage which is a catastrophic scenario. Consequently, careful management of solitary kidney patients will lead to conservative approaches and will affect the results (23). 
On univariate binary logistic regression analysis of predictor variables of complications, it was linked to the complexity of the stones. Also, acute dilatation of the tract was related to more complications. This is since acute dilatation of the tract was done in most of the cases $(78 \%)$. In literature, the operative time was positively correlated to the complication rate (24).

Only $12(8 \%)$ patients required blood transfusion in this study. In contrast, The CROES study showed the same rates of hemorrhage between solitary and bilateral kidneys groups (10.2\%), but rates of blood transfusion were significantly higher in solitary kidney group, this can be explained by the increased caution given to this group (5). On univariate binary logistic regression analysis of predictor variables of bleeding, there was an association between the number of accessed tracts and the rate of bleeding and blood transfusion (P-value $=0.008)$ as well as there was a correlation between the drop-in hematocrit and the number of tracts. This can be explained by the fact of the compensatory hypertrophy of the solitary kidney which is a normal physiological response (25). However; we should emphasize that in our study there were only $16(11 \%)$ patients had a double accessed tract. El-Nahas et al found that only functioning kidney, staging stones, more than one tract, and an inexperienced operator were a causes for renal hemorrhage (26). Torricelli also found that a second dilatation of the tract was significantly associated with bleeding (24).

In our study, there was a slight increase in the postoperative serum creatinine after one day. The CROES study documented a corresponding increase in serum creatinine immediately at the postoperative period in all PNL patients (5). Canes et al reported that mean serum creatinine measures after PNL in patients with a solitary kidney were elevated on the first postoperative day (27). Numerous punctures with dilatation and movement of nephroscope broaden the parenchymal damage, which may be an explanation of this affection. Handa et al also have recorded that after a period, a PNL in humans and animals creates a small but permanent parenchymal fibrosis at the nephrostomy site (28). It can heal, but it can also cause fibrosis that stretches away from the tract. It is not yet proven if the punctured papilla can recover its normal role later on or not (29). The three months follow up of our study revealed a significant improvement in creatinine and eGFR levels. This could be explained by the eradication of obstruction and infection associated with renal calculi. We think that the most harmful effect on renal function is prolonged obstruction. This issue is debatable in literature, some studies confirmed this finding (5) (27) (30) while others denied this improvement (31) (32).

The fact that this is the only prospective study with a large sample size (150 patients) talking about complications of PNL in patients with a solitary kidney adds a great advantage to this work. However; our study has some limitations as there was no control group of patients, the 3 months follow-up was short and the biochemical makeup of the stones was not captured in this study.

\section{Conclusion:}

PNL is a challenging procedure in solitary kidneys; however high SFRs can be done with a low rate of major complications. The complexity of the stones, acute dilatation of the tract, and 
SOHAG MEDICAL JOURNAL

Vol. 24 No. 2 April 2020

operative time are associated with more complications. Multiple tracts have a significant effect on intraoperative bleeding so a second puncture in a solitary kidney should be done cautiously. There is an increase in serum creatinine postoperatively with improvement in the renal function at the follow-up. PNL is an effective choice for patients with stones in a solitary kidney.

\section{Abbreviations: \\ PNL = Percutaneous Nephrolithotomy \\ SFR $=$ Stone Free Rate \\ eGFR = estimated Glomerular Filtration \\ Rate \\ BMI = Body Mass Index \\ NCCT $=$ Non Contrast Computed \\ Tomography \\ IVU = Intravenous Urography \\ GSS = Guy's Stone Score \\ SFU = Society of Fetal Urology \\ CKD-EPI = The Chronic Kidney \\ Disease Epidemiology Collaboration \\ equation \\ HGB = Hemoglobin \\ CROES = Clinical Research Office of \\ Endourological Society}

\section{References:}

1. Skolarikos A, Straub M, Knoll T, Sarica K, Seitz C, Petřík A, et al. Metabolic evaluation and recurrence prevention for urinary stone patients: EAU guidelines. Eur Urol. 2015 Apr;67(4):750-63.

2. Tiselius HG, Ackermann D, Alken P, Buck C, Conort P, Gallucci M; Working Party on Lithiasis, European Association of Urology. Guidelines on urolithiasis. Eur Urol. 2001 Oct;40(4):362-71.

3. Bres-Niewada E. Solitary kidney - a clinical challenge for endourologist. Cent European J Urol. 2016;69(1):96-7.

4. Fernström I, Johansson B. Percutaneous pyelolithotomy. A new extraction technique. Scand J Urol Nephrol. 1976;10(3):257-9.
5. Bucuras V, Gopalakrishnam G, Wolf JS Jr, Sun Y, Bianchi G, Erdogru T, et al.; CROES PCNL Study Group. The clinical research office of the endourological society percutaneous nephrolithotomy global study: nephrolithotomy in 189 patients with solitary kidneys. J Endourol. 2012 Apr;26(4):336-41.

6. Liu C, Cui Z, Zeng G, Wan SP, Li J, Zhu $\mathrm{W}$, et al. The optimal minimally invasive percutaneous nephrolithotomy strategy for the treatment of staghorn stones in a solitary kidney. Urolithiasis. 2016 Apr;44(2):149-54.

7. Zhong W, Zhao Z, Wang L, Swami S, Zeng G. Percutaneous-based management of Staghorn calculi in solitary kidney: combined mini percutaneous nephrolithotomy versus retrograde intrarenal surgery. Urol Int. 2015;94(1):70-3.

8. Fernbach SK, Maizels M, Conway JJ. Ultrasound grading of hydronephrosis: introduction to the system used by the Society for Fetal Urology. Pediatr Radiol. 1993;23(6):478-80.

9. Thomas K, Smith NC, Hegarty N, Glass JM. The Guy's stone score-grading the complexity of percutaneous nephrolithotomy procedures [Internet]. Urology. 2011 Aug;78(2):277-81.

10. Levey AS, Stevens LA, Schmid CH, Zhang YL, Castro AF 3rd, Feldman HI, et al.; CKD-EPI (Chronic Kidney Disease Epidemiology Collaboration). A new equation to estimate glomerular filtration rate. Ann Intern Med. 2009 May;150(9):604-12.

11.Al-Ali BM, Patzak J, Lutfi A, Pummer $\mathrm{K}$, Augustin H. Impact of urinary stone volume on computed tomography stone attenuations measured in Hounsfield units in a large group of Austrian patients with urolithiasis. Cent European J Urol. 2014;67(3):289-95

12. Süelözgen T, Isoglu CS, Turk H, Yoldas M, Karabicak M, Ergani B, et al. Percutaneous nephrolithotomy with oneshot dilation method: is it safe in patients who had open surgery before? [Internet]. Can Urol Assoc J. 2016 Mar-Apr;10(3- 
SOHAG MEDICAL JOURNAL

Vol. 24 No. 2 April 2020

4):E132-5.

13. Hosseini MM, Yousefi A, Hassanpour A, Jahanbini S, Zaki-Abbasi M. Percutaneous nephrolithotomy in solitary kidneys: experience with 412 cases from Southern Iran [Internet]. Urolithiasis. 2015 Jun;43(3):233-6.

14. Torrecilla Ortiz C, Meza Martínez AI, Vicens Morton AJ, Vila Reyes H, Colom Feixas S, Suarez Novo JF, et al. Obesity in percutaneous nephrolithotomy. Is body mass index really important? Urology. 2014 Sep;84(3):538-43.

15. Seitz C, Desai M, Häcker A, Hakenberg OW, Liatsikos E, Nagele $U$, et al. Incidence, prevention, and management of complications following percutaneous nephrolitholapaxy. Eur Urol. 2012 Jan;61(1):146-58.

16. Bootsma AM, Laguna Pes MP, Geerlings SE, Goossens A. Antibiotic prophylaxis in urologic procedures: a systematic review. Eur Urol. 2008 Dec;54(6):1270-86.

17. Mariappan P, Smith G, Moussa SA, Tolley DA. One week of ciprofloxacin before percutaneous nephrolithotomy significantly reduces upper tract infection and urosepsis: a prospective controlled study. BJU Int. 2006 Nov;98(5):1075-9.

18.Dirim A, Turunc T, Kuzgunbay B, Hasirci E, Tekin MI, Ozkardes H. Which factors may effect urinary leakage following percutaneous nephrolithotomy? World J Urol. 2011 Dec;29(6):761-6.

19.Mousavi-Bahar SH, Mehrabi S, Moslemi MK. Percutaneous nephrolithotomy complications in 671 consecutive patients: a single-center experience. Urol J. 2011;8(4):271-6.

20.Shin TS, Cho HJ, Hong SH, Lee JY, Kim SW, Hwang TK. Complications of Percutaneous Nephrolithotomy Classified by the Modified Clavien Grading System: A Single Center's Experience over 16 Years. Korean J Urol. 2011 Nov;52(11):769-75.

21.Bjurlin MA, O'Grady T, Kim R, Jordan MD, Goble SM, Hollowell CM. Is routine postoperative chest radiography
Predictive Factors of Complications of PNL in Solitary Ahmed Sabri Mahmoud

needed after percutaneous nephrolithotomy? Urology. 2012 Apr;79(4):791-5.

22. Lojanapiwat B, Prasopsuk S. Upper-pole access for percutaneous nephrolithotomy: comparison of supracostal and infracostal approaches. J Endourol. 2006 Jul;20(7):491-4.

23. Shi X, Peng Y, Li L, Li X, Wang Q, Zhang W, et al. Renal function changes after percutaneous nephrolithotomy in patients with renal calculi with a solitary kidney compared to bilateral kidneys. BJU Int. 2018 Oct;122(4):633-8.

24. Torricelli FC, Padovani GP, Marchini GS, Vicentini FC, Danilovic A, Reis ST, et al. Percutaneous nephrolithotomy in patients with solitary kidney: a critical outcome analysis [Internet]. Int Braz J Urol. 2015 May-Jun;41(3):496-502.

25. Resorlu B, Kara C, Oguz U, Bayindir M, Unsal A. Percutaneous nephrolithotomy for complex caliceal and staghorn stones in patients with solitary kidney. Urol Res. 2011 Jun;39(3):171-6.

26. El-Nahas AR, Shokeir AA, El-Assmy AM, Mohsen T, Shoma AM, Eraky I, et al. Post-percutaneous nephrolithotomy extensive hemorrhage: a study of risk factors. J Urol. 2007 Feb;177(2):576-9.

27. Canes D, Hegarty NJ, Kamoi K, Haber GP, Berger A, Aron M, et al. Functional outcomes following percutaneous surgery in the solitary kidney. J Urol. 2009 Jan;181(1):154-60.

28. Handa RK, Evan AP, Willis LR, Johnson CD, Connors BA, Gao S, et al. Renal functional effects of multiple-tract percutaneous access. J Endourol. 2009 Dec;23(12):1951-6.

29. Williams SK, Leveillee RJ. Management of staghorn calculus: single puncture with judicious use of the flexible nephroscope. Curr Opin Urol. 2008 Mar;18(2):224-8.

30. El-Tabey NA, El-Nahas AR, Eraky I, Shoma AM, El-Assmy AM, Soliman SA, et al. Long-term functional outcome of percutaneous nephrolithotomy in solitary kidney. Urology. 2014 May;83(5):10115. 
SOHAG MEDICAL JOURNAL

Vol. 24 No. 2 April 2020

31. Streem SB, Zelch MG, Risius B, Geisinger MA. Percutaneous extraction of renal calculi in patients with solitary kidneys. Urology. 1986 Mar;27(3):24752.

32. Liou LS, Streem SB. Long-term renal functional effects of shock wave
Predictive Factors of Complications of PNL in Solitary Ahmed Sabri Mahmoud

lithotripsy, percutaneous nephrolithotomy and combination therapy: a comparative study of patients with solitary kidney. J Urol. 2001 Jul;166(1):36. 